\title{
Evaluation of predictive measurements of excess weight in brazilian children
}

\author{
Luryê Soria ${ }^{1}$ \\ Daniela de S. Teixeira ${ }^{1}$ \\ (iD) Daniel N. Polese ${ }^{2}$ \\ Maria T. B. Fernandes ${ }^{3}$
}

1. Public Health Faculty of USP, São Paulo, SP, Brasil 2. Federal University of São Paulo/Department of Psychobiology, São Paulo, SP, Brasil 3. University of São Paulo/Department of Pediatrics, São Paulo, SP, Brasil

KEYWORDS: Obesity. Child. Anthropometry.

http://dx.doi.org/10.1590/1806-9282.65.5.663

\section{INTRODUCTION}

Obesity is considered a chronic non-communicable disease (NCD), of multifactor etiology. Its prevalence is rising rapidly, even in children and adolescents; its consequent metabolic changes, which before were only found in the adult population, can already be found in the younger population ${ }^{1.2}$. Among the factors most closely associated with obesity is the change in eating habits and lifestyle. Overall, there has been a change in diet, characterized by the high consumption of high-energy-density foods, rich in simple sugars and fat, combined with a reduction of physical exercises and an increase of screen time ${ }^{2,3}$.

The Body Mass Index is the main instrument used to identify obesity. However, the BMI is not able to evaluate central obesity, the main predictor of comorbidities associated with obesity ${ }^{4}$. A measurement that can be used for this purpose is the waist circumference (WC), which is considered a good indicator of visceral fat, presenting a strong relationship with atherosclerotic cardiovascular diseases, insulin resistance, and the metabolic syndrome ${ }^{5}$. Like the $\mathrm{WC}$, the waist/height index $(\mathrm{W} / \mathrm{H})$ is also a tool used to measure the deposition of fat in the abdominal region, presenting an important correlation with cardiovascular risk factors ${ }^{6}$. Current research reported that the circumference of the neck (NC) could identify patients with obesity and overweight, which can be directly related to factors associated with metabolic syndrome ${ }^{7}$.

The objective of this study is to verify the distribution of body fat using the waist and neck circumference and the $\mathrm{W} / \mathrm{H}$ index and to compare $\mathrm{NC}, \mathrm{WC}$ and the N/H index with the BMI of children and adolescents aged 2-14 years treated by the Projeto Bandeira Científica in Acreúna (GO) in 2016. 


\section{METHODS}

This is a cross-sectional study with children and adolescents aged 2-14 years treated by the Projeto Bandeira Científica in the city of Acreúna (GO), between the second and third weeks of December 2016.

The Projeto Bandeira Científica project was created in the Medical Faculty of USP in 1957. It is an initiative of university extension led by students from various programs of the University of São Paulo.

The city of Acreúna is a municipality in the Serra do Caiapó mountain range. It has a territorial extension of $1,824 \mathrm{~km}^{2}$ and an estimated population of 21,905 inhabitants, of which 5,049 were children between 0-14 years old in 2010. It is a predominantly urban area (86.70\%), and its economy revolves around agriculture and services. Its MHDI (Municipal Human Development Index) is 0.686 and has full coverage of the Family Health Program.

The directors of the project made eight previous visits to the city of Acreúna with the objective to learn about the reality of local health, present the initiative and invite the public to participate in the project. A list of people interested in receiving care via the project was drawn up, and they were called on the day the project team started their work. The project team was distributed daily into two different locations, organized every day in different spaces made available by the city hall, in order to facilitate the access of citizens. The units were set up in schools that had enough space for the team and the work material. The selection of the study population was made using an anthropometric assessment in the care units of the Project, where children and adolescents up to 18 years and 11 months old, the elderly and pregnant women were required to go through. A total of 205 children and adolescents were evaluated.

Were excluded from the research children and adolescents who had the following chronic diseases: encephalopathies, lung diseases, heart, liver, and kidney diseases, HIV infection, genetic syndromes, and oncologic diseases. Children aged between 2 and 4 years were characterized as preschoolers; from 5 to 10 years, as schoolchildren; and those from 11 to 14 years old, as adolescents ${ }^{8}$.

The methodological instruments used were: a questionnaire for collecting personal, anthropometric, and clinical data, and the following measurements and index:

Weight and height were measured according to the standardized methodology ${ }^{9}$. The NC was mea- sured using an inelastic measuring tape positioned at the middle point of the neck, at the level of the thyroid cartilage, with the individual standing up, looking forward and breathing normally ${ }^{\mathbf{1 0}}$. The WC was measured with a measuring tape by obtaining the smallest circumference between the anterior superior iliac crest and the last costal arch"1. The index $(\mathrm{W} / \mathrm{H})$ is the relationship between waist and height measurements, and the values were separated into two groups: $<0.5$ and $>0.5$ - the latter indicating an increased risk for cardiovascular diseases ${ }^{12}$.

To assess their nutritional status, children and adolescents were classified according to the BMI indicated per age in $\mathrm{z}$-score (BMI/I), using as a reference the growth curves of the World Health Organization $^{13}$ and the WHO cut-offs for overweight and obesity risk ${ }^{14}$. The Anthro Plus software, developed by the $\mathrm{WHO}^{15}$ was used for classifying the nutritional status.

In the statistical analysis, the numerical variables were evaluated using averages and standard deviations and the categorical variables using absolute frequencies. The software used was SPSS Statistics 20. We considered the BMI a outcome variable and the WC, NC, and W/H index predictor variables. Analyses were carried out using Pearson correlation and linear regression between variables and outcome predictors. Then, we made the ROC curve, accuracy, sensitivity, specificity, positive and negative predictive values and precision by age for the variables: $\mathrm{W} / \mathrm{H}$ index, WC, and NC; the level of significance was set at $\mathrm{p}<0.05$.

The research was approved by the Research Ethics Committee of the Medical Faculty of the University of São Paulo (Process number: 119885/2016), and the parents or guardians signed informed consent for the use of the collected data.

\section{RESULTS}

In total, 205 children and adolescents took part in the research, with an average age of 8 years and 2 months (SD $=+3$ years and 6 months), $51.20 \%$ $(n=105)$ males. Table 1 presents the average anthropometric measurements collected, minimum, maximum, mean and standard deviation, in addition to the classifications according to the $\mathrm{z}$-score.

Regarding nutritional status according to BMI/ age, $67.80 \%$ were classified as eutrophic, $3.41 \%$ as underweight, $4.87 \%$ as in risk of overweight, $12.68 \%$ 
TABLE 1 - CHARACTERIZATION OF THE POPULATION STUDIED ACCORDING TO THE ANTHROPOMETRIC DATA (ACREÚNA, 2016).

\begin{tabular}{l|l|l|l|l|l} 
& N & $\begin{array}{l}\text { Mini- } \\
\text { mum }\end{array}$ & $\begin{array}{l}\text { Maxi- } \\
\text { mum }\end{array}$ & $\begin{array}{l}\text { Aver- } \\
\text { age }\end{array}$ & $\begin{array}{l}\text { Standard } \\
\text { deviation }\end{array}$ \\
\hline Age (years) & 205 & 2.03 & 14.99 & 8.13 & 3.56 \\
\hline Weight (kg) & 205 & 9.10 & 82.90 & 30.69 & 15.81 \\
\hline Height (cm) & 205 & 81.00 & 177.20 & 127.23 & 22.46 \\
\hline Weight/Age* & 134 & -3.96 & 3.44 & 0.17 & 1.28 \\
\hline Height/Age & 205 & -3.66 & 2.44 & -0.03 & 1.10 \\
\hline $\begin{array}{l}\text { BMI/Age } \\
(z-s c o r e)\end{array}$ & 205 & -3.20 & 4.26 & 0.35 & 1.34 \\
\hline BMI & 205 & 12.30 & 32.10 & 17.68 & 3.86 \\
\hline WC (cm) & 205 & 20.50 & 99.80 & 60.32 & 11.68 \\
\hline NC (cm) & 205 & 16.90 & 44.50 & 28.58 & 3.82 \\
\hline W/H Index & 205 & 0.16 & 0.65 & 0.48 & 0.06 \\
\hline
\end{tabular}

${ }^{\star}$ The classification according to weight/age applies only for children from 0 to 10 years old.

as overweight, and $11.22 \%$ as obese (Table 2). Concerning gender, of 100 girls assessed, 29.75\% were eutrophic, $1.95 \%$ had low weight, $2.44 \%$ risk of overweight, $8.78 \%$ were overweight, and $5.85 \%$ were obese. As to males, $38.04 \%$ of the boys were eutrophic, $1.46 \%$ had low weight, $2.44 \%$ risk of overweight, $3.90 \%$ were overweight, and $5.36 \%$ were obese (Table 2). The nutritional status of overweight/obesity was more frequent in children over 10 years old than in other age groups.

The average value of neck and waist circumference was $28.56 \pm 3.82 \mathrm{~cm}$ and $60.32 \pm 11.68 \mathrm{~cm}$, respectively. In $66.30 \%(\mathrm{n}=136)$, the classification of waist circumference per height $(\mathrm{W} / \mathrm{H})$ was lower than 0.5 and in $33.70 \%(n=69)$ it was greater than this value (Table 2$)$.

The values of the correlation and simple linear
FIGURE 1. ROC CURVES FOR THE W/H INDEX, WC, AND NC IN RELATION TO PEDIATRIC AGE GROUPS.

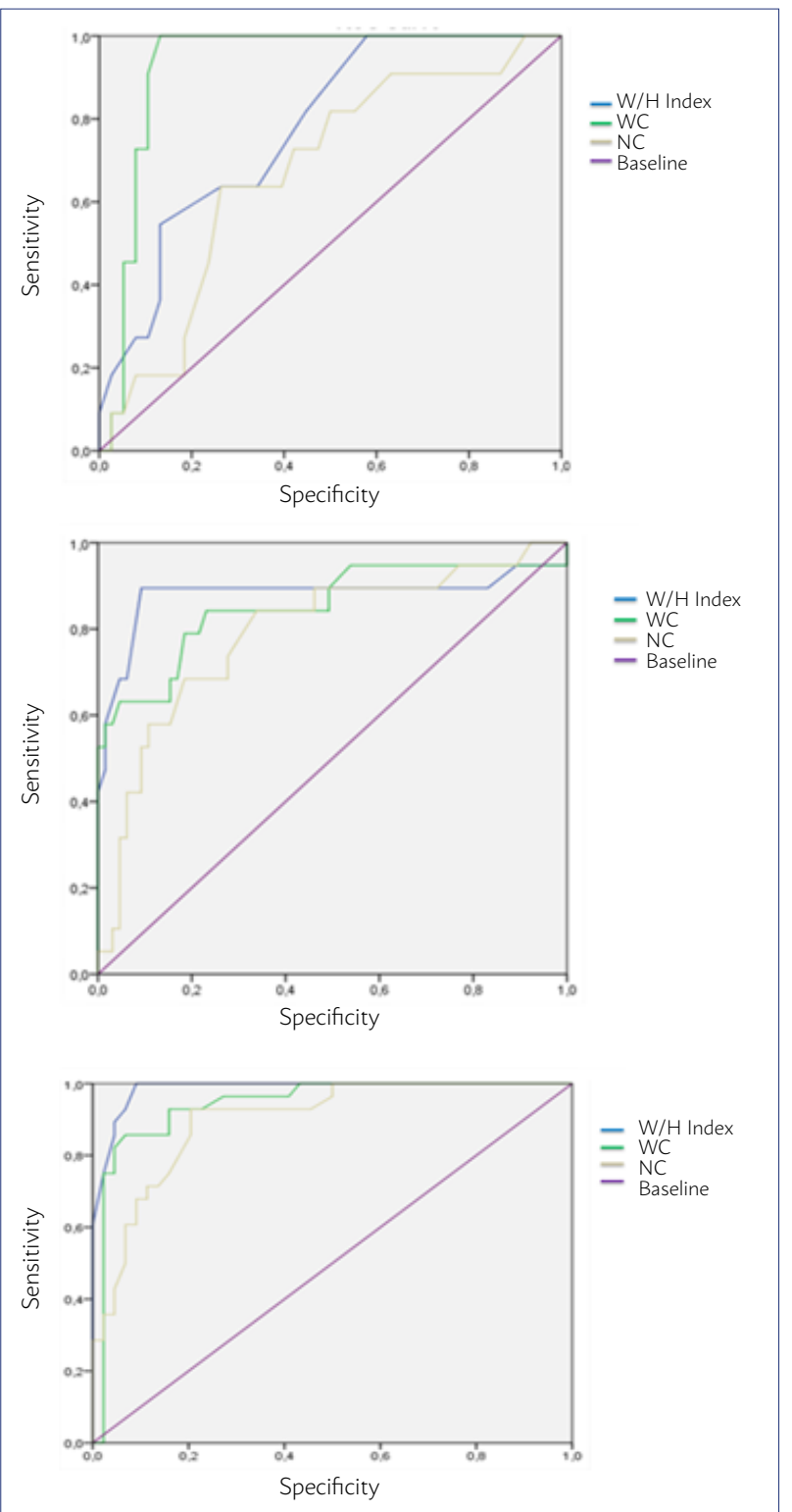

A. ROC curve for children 2-5 years old. B. ROC curve for children 5-10 years old $\mathbf{C}$. ROC curve for children over 10 years old

TABLE 2 - CLASSIFICATION OF NUTRITIONAL STATUS ACCORDING TO BMI/AGE IN RELATION TO AGE, GENDER, AND CLASSIFICATION OF THE INDEX W/H INDEX (ACREÚNA, 2016).

\begin{tabular}{l|l|l|l|l|l|l|l}
\multicolumn{2}{l|}{} & $\begin{array}{l}\text { Low weight } \\
\%(n)\end{array}$ & $\begin{array}{l}\text { Eutrophy } \\
\%(n)\end{array}$ & $\begin{array}{l}\text { Overweight } \\
\text { risk \%(n) }\end{array}$ & $\begin{array}{l}\text { Overweight } \\
\%(n)\end{array}$ & $\begin{array}{l}\text { Obesity } \\
\%(n)\end{array}$ & Total \\
\hline \multirow{2}{*}{ Age range } & $2 \mid-5$ & 0 & $18.53(38)$ & $4.87(10)$ & $0.48(1)$ & 0 & 49 \\
\cline { 2 - 9 } & $5 \mid-10$ & $1.95(4)$ & $29.75(61)$ & 0 & $4.39(9)$ & $4.87(10)$ & 84 \\
\cline { 2 - 9 } & $10 \mid-15$ & $1.46(3)$ & $19.51(40)$ & 0 & $7.8(16)$ & $6.35(13)$ & 72 \\
\hline Gender & Female & $1.95(4)$ & $29.75(61)$ & $2.44(5)$ & $8.78(18)$ & $5.85(12)$ & 100 \\
\hline & Male & $1.46(3)$ & $38.04(78)$ & $2.44(5)$ & $3.9(8)$ & $5.36(11)$ & 105 \\
\hline $\begin{array}{l}\text { Classification } \\
\text { W/H Index }\end{array}$ & $>0.5$ & $3.41(7)$ & $54.63(112)$ & 0 & $6.34(13)$ & $1.95(4)$ & 136 \\
\hline Total & 0.5 & 0 & $13.17(27)$ & $4.87(10)$ & $6.34(13)$ & $9.26(19)$ & 69 \\
\hline
\end{tabular}


regression between $\mathrm{BMI}, \mathrm{WC}, \mathrm{NC}$, and $\mathrm{W} / \mathrm{H}$ Index showed us that the increase in 1 centimeter in WC entails an increase of 0.274 in $\mathrm{BMI}\left(\mathrm{R}=0.830 ; \mathrm{R}^{2}=0.688\right.$; $p=0.001 ; \beta=0.274)$, the increase in 1 centimeter in NC generates an increase of 0.717 in BMI $\left(R=0.711 ; R^{2}\right.$ $=0.506 ; p=0.001 ; \beta=0.717)$ and the increase of 1 millimeter in the W/H Index leads to an increase of 2.770 in $\operatorname{BMI}\left(\mathrm{R}=0.447 ; \mathrm{R}^{2}=0.200 ; \mathrm{p}=0.001 ; \beta=2.770\right)$.

ROC curves were drawn to identify the best instrument for the anthropometric assessment of children and adolescents. To do that, we calculated the areas under the ROC curves (AUC) for WC, NC, and $\mathrm{W} / \mathrm{H}$ Index per the age ranges. These were statistically significant $(p<0.05)$, except for NC in children up to 5 years old (Figure 1).

Table 3 shows the different cutoff points for WC, $\mathrm{NC}$, and $\mathrm{W} / \mathrm{H}$ Index and their respective values of accuracy, sensitivity, specificity, positive and negative predictive values, and precision, separated by age and sex. In children aged 2 to 5 years, the WC has proved to be the best instrument (89.8 $\pm 0.04 \%)$, and in children from 5 to 10 years and over 10 years, the W/H Index had the best results $(90.1 \pm 0.03 \%$ and $94.4 \pm 0.03 \%$, respectively).

\section{DISCUSSION}

This study evaluated the relationship between the $\mathrm{WC}, \mathrm{NC}$, and W/H Index variables with the BMI in children and adolescents. The main result found was that the WC of children younger than 5 years and the $\mathrm{W} / \mathrm{H}$ Index of children older than 5 years have proved to be accurate measurements to identify excess weight.
In the present study, $23.90 \%$ of the individuals were classified as having excess weight $(12.68 \%$ overweight and $11.22 \%$ obese), the majority of them females over 10 years old. In the study by Petroski et al. ${ }^{16}, 6.80 \%$ of the schoolchildren were classified with excess weight, and there was also a predominance of females over 10 years old. Silva et al. ${ }^{17}$ found a higher percentage of overweight among the children analyzed, but lower rates of obesity (14.50\% and $8.30 \%$, respectively), and Pelegrini et al. ${ }^{18}$ observed that $24.30 \%$ of their study population showed excess weight. Such statistical variations are possibly due to regional variations. By analyzing the data from the 2008-2009 HBS, we found that $33.50 \%$ of children from 5 to 9 years old are overweight, while in adolescents from 10 to 19 years old the number drops to $20.50 \%$. Thus, the prevalence statistics observed in the present study lies between the HBS values for children and adolescents ${ }^{19}$.

Regarding the evaluation per genre, this study found that the prevalence of excess weight is higher in females than in males, with $8.78 \%$ of the girls overweight and $5.85 \%$ obese, while these number in males are $3.90 \%$ and $5.36 \%$, respectively. The data from the 2008-2009 HBS show that excess weight is slightly higher in males: $32 \%$ of female children from 5 to 9 years old have excess weight, whereas this value increases to $34.80 \%$ in males; in the age range of 10 to 19 years, the HBS data show that the prevalence of excess weight is $19.40 \%$ in females and $21.70 \%$ in males $^{19}$. The rates of excess weight and obesity are very high. In Brazil, over half of the adult population

TABLE 3 - CUT-OFF POINTS, SENSITIVITY, SPECIFICITY, ACCURACY, POSITIVE AND NEGATIVE PREDICTIVE VALUES FOR WC, NC AND W/H INDEX (ACREÚNA, 2016).

\begin{tabular}{|c|c|c|c|c|c|c|c|c|c|c|}
\hline Age range & & $\begin{array}{l}\text { Entire sam- } \\
\text { ple }(n=205)\end{array}$ & $\begin{array}{l}\text { Females } \\
(n=100)\end{array}$ & $\begin{array}{l}\text { Males } \\
(n=105)\end{array}$ & $A(\%)$ & $\mathrm{S}(\%)$ & $E(\%)$ & $\begin{array}{l}\text { PPV } \\
(\%)\end{array}$ & $\begin{array}{l}\text { NPV } \\
(\%)\end{array}$ & $\mathrm{P}(\%)$ \\
\hline \multirow[t]{3}{*}{$2-5$ years } & W/H Index & 0.55 & 0.55 & 0.54 & 80 & 55 & 87 & 55 & 87 & 80 \\
\hline & WC (cm) & 52.40 & 52.40 & 53.00 & 90 & 69 & 100 & 100 & 87 & 90 \\
\hline & $\mathrm{NC}(\mathrm{cm})$ & 27.50 & 26.20 & 26.60 & 76 & 40 & 80 & 18 & 92 & 76 \\
\hline \multirow[t]{3}{*}{ 5-10 years } & W/H Index (cm) & 0.49 & 0.49 & 0.49 & 90 & 74 & 97 & 89 & 90 & 90 \\
\hline & $W C(\mathrm{~cm})$ & 63.00 & 63.00 & 65.80 & 88 & 80 & 90 & 63 & 95 & 88 \\
\hline & $\mathrm{NC}(\mathrm{cm})$ & 29.50 & 32.00 & 29.50 & 82 & 61 & 88 & 58 & 89 & 82 \\
\hline \multirow{3}{*}{$\begin{array}{l}\text { Over } 10 \\
\text { years }\end{array}$} & W/H Index (cm) & 0.46 & 0.49 & 0.46 & 94 & 88 & 100 & 100 & 91 & 94 \\
\hline & WC (cm) & 73.00 & 73.50 & 73.00 & 90 & 89 & 91 & 86 & 93 & 90 \\
\hline & $\mathrm{NC}(\mathrm{cm})$ & 30.70 & 30.90 & 33.00 & 85 & 74 & 95 & 93 & 80 & 85 \\
\hline
\end{tabular}

A: accuracy; S: sensitivity; E: specificity; PPV: positive predictive value; NPV: negative predictive value; P: precision; WC (waist circumference); NC (neck circumference); W/H Index (waist/height). Values calculated for the total sample. 
is overweight ${ }^{20}$, a situation that affects both genders similarly.

The increase in ultra-processed food consumption, or even of minimally processed ones, over in natura food, and the increasingly sedentary lifestyle of children and adolescents, characterized by an increase in screen time ${ }^{3}$, have been associated with high rates of overweight among children.

The results of the correlation between BMI and $\mathrm{NC}, \mathrm{WC}$ and $\mathrm{W} / \mathrm{H}$ Index show that the NC and WC are strongly correlated with the BMI. The W/H Index presented a moderate correlation with BMI (strong positive correlation: $r=0.70-0.89$ ) and moderate: $r$ $=0.40-0.69$ ). Also, the ROC curves indicate that the AUC of WC was higher in children from 2 to 5 years old, showing it to be the best instrument for indication of excess weight. In children aged 5 to 14 years, the W/H Index proved to be the best instrument. Another point that we were able to observe during the analysis is that $\mathrm{WC}, \mathrm{NC}$, and the $\mathrm{W} / \mathrm{H}$ Index proved to be more significant with increasing age, i.e., there is a proportional and positive relationship with age.

In adults, the WC is a measurement widely used for verification of central obesity, which is related to the risk of cardiovascular diseases. Recently, this parameter has been proposed as an indirect measure of central obesity in children and adolescents ${ }^{21.22}$. The results found allow us to affirm that the WC provides very relevant and consistent information on the central body fat deposition in children when compared with the BMI. Corroborating the findings of this study, the studies of Soar et al. ${ }^{23}$ and Ricardo et al. ${ }^{24}$ also found a strong correlation between WC and BMI.

The present study showed that $33.70 \%$ of children and adolescents had a waist/height ratio over 0.5, i.e., a large fat tissue deposition in the abdominal region. This value is much greater than one found by Ricardo et al. ${ }^{24}$, who found that $11.90 \%$ of children between 6 and 10 years old had abdominal adiposity and is also greater than the one found in the McCarthy and Ashwell ${ }^{25}$ study, in which a $11.70 \%$ prevalence was observed. According to Pereira et al. ${ }^{26}$, the W/H index can be considered a good indicator of abdominal adiposity, even better than the isolated measurement of waist circumference, because it takes into consideration the height of the individual and allows us to establish a single cut-off point. The AUC shows that the $\mathrm{W} / \mathrm{H}$ Index is a good tool to identify excess weight, which is confirmed by high sensitivity and specificity values in all age groups. However, according to these results, we observed that, in younger children (2-5 years), this is not the best instrument, which corroborates a study conducted with children in Norway, according to which the W/H Index has lower sensitivity and specificity values in this age group ${ }^{27}$.

The NC, a measurement that has been studied as a potential indicator of excess weight, was evaluated in children and adolescents. The results showed a strong positive correlation between NC and BMI, compatible with the findings of Lou et al. ${ }^{28}$, Coutinho et al. ${ }^{29}$ And Nafiu et al. ${ }^{10}$. In this study, the NC was correlated with BMI and became more significant as a predictor of excess weight as age increased, being indicated as a screening tool in older children. In contrast, the results also indicate that this is a less effective tool than others known since the NC had the lowest values of accuracy, sensitivity, specificity, positive and negative predictive values, and precision when compared with the WC and the W/H Index. The NC may reflect overweight and obesity in children and adolescents, but not in isolation; it needs to be associated with other measurements discussed in this work.

The limitations of our study are related to the gold standard parameter used for the analyses: BMI, which is known to be a high-sensitivity and low-specificity tool in the detection of excess weight. It would be interesting to compare the predictive variables with more reliable parameters of body composition diagnosis, such as densitometry by dual emission of X-rays and bioimpedance, but the dynamics and reality of the project did allow the collection of such data. Furthermore, the data collection was performed by the entire nutrition team who participated in the project in 2016 and, even though they received training to collect anthropometric measures, that did not avoid data collection errors, which are always present in studies such as this one, due to the interpersonal variation. Despite its limitations, this study showed that anthropometric measures such as WC, NC and W/H Index are useful to evaluate the nutritional status of children and adolescents in general.

\section{CONCLUSION}

After the analyses, we concluded that the children and adolescents treated by the Projeto Bandeira Científica showed a prevalence of $23.90 \%$ of excess weight, which is considered a high prevalence. Also, $33.70 \%$ had a W/H Index over 0.5, showing that approximately $1 / 3$ had excess abdominal fat, which rep- 
resents a risk for developing cardiometabolic diseases.

In the analysis by age groups using the ROC curve, we observed that among children aged 2 to 5 years, the WC presented a higher AUC than the W/H Index and NC. Whereas in children from 5 to 14 years old, the W/H index presented higher AUC than the WC and NC.

In summary, the WC of children younger than 5 years and the $\mathrm{W} / \mathrm{H}$ Index of children older than 5 years have proved to be accurate measurements to identify excess weight.

PAlaVRAS-ChaVE: Obesidade. Criança. Antropometria.

\section{REFERENCES}

1. Pinheiro ARO, Freitas SFT, Corso ACT. Uma abordagem epidemiológica da obesidade. Rev Nutr. 2004;17(4):523-33.

2. Oliveira CL, Fisberg M. Obesidade na infância e adolescência: uma verdadeira epidemia. Arq Bras Endocrinol Metabol. 2003;47(2):107-8.

3. Soares LD, Petroski EL. Prevalência, fatores etiológicos e tratamento da obesidade infantil. Rev Bras Cineantropom Desempenho Hum. 2003;5(1):63-74

4. Taheri M, Kajbaf TZ, Thaheri MR, Aminzadeh M. Neck circumference as a useful marker for screening overweight and obesity in children and adolescents. Oman Med J. 2016;31(3):170-5.

5. Silva CC, Xambon MP, Vasques AC, Rodrigues AM, Camilo DF, Antonio $M \hat{A}$, et al. Neck circumference as a new anthropometric indicator for prediction of insulin resistance and components of metabolic syndrome in adolescents: Brazilian Metabolic Syndrome Study. Rev Paul Pediatr. 2014;32(2):221-9

6. Ho SY, Lam TH, Janus ED; Hong Kong Cardiovascular Risk Factor Prevalence Study Steering Committee. Waist to stature ratio is more strongly associated with cardiovascular risk factors than other simple anthropometric indices. Ann Epidemiol. 2003;13(10):683-91.

7. Frizon V, Boscaini $C$. Circunferência do pescoço, fatores de risco para doenças cardiovasculares e consumo alimentar. Rev Bras Cardiol. 2013;26(6):426-34.

8. Sociedade Brasileira de Pediatria. Calendário Puericultura; 2014. [cited 2018 March 19] Available from: www.sbp.com.br

9. Frisancho AR. Anthropometric standards for the assessment of growth and nutritional status. Ann Arbor: University of Michigan Press; 1990.

10. Nafiu OO, Burke C, Lee |, Voepel-Lewis T, Malviya S, Tremper KK. Neck circumference as a screening measure for identifying children with high body mass index. Pediatrics. 2010;126(2):e306-10.

11. Taylor RW, Jones IE, Williams SM, Goulding A. Evaluation of waist circumference, waist-to-hip ratio, and the conicity index as screening tools for the high trunk fat mass, as measured by dual-energy $X$-ray absorptiometry, in children aged 3-19 y. Am | Clin Nutr. 2000;72(2):490-5.

12. Ashwell M, Lejeune $S, M c P h e r s o n ~ K$. Ratio of waist circumference to height may be a better indicator of need for weight management. BM]. 1996;312(7027):377.

13. World Health Organization. Multicentre Growth Reference Study Group. WHO Child Growth Standards: Methods and development. Geneva: World Health Organization; 2006

14. Onis $M$, Lobstein $T$. Defining obesity risk status in the general childhood population: which cut-offs should we use? Int | Pediatr Obes. 2010;5(6):458-60

15. Onis M, Onyango AW, Borghi E, Siyam A, Nishida C, Siekmann |. Development of a WHO growth reference for school-aged children and adolescents. Bull World Health Organ. 2007;85(9):660-7.

\section{Conflict of interest}

Nothing to declare.

\section{Source of funding}

Foundation of the Medical Faculty and the Public Health Faculty of USP.

\section{Acknowledgments}

The Projeto Bandeira Científica, for the support offered during the development of this study.

16. Petroski EL, Silva RJS, Pelegrini A. Crescimento físico e estado nutricional de crianças e adolescentes da região de Cotinguiba, Sergipe. Rev Paul Pediatr. 2008;26(3):206-11

17. Silva GAP, Balaban G, Motta MEFA. Prevalence of overweight and obesity in children and adolescents of different socioeconomic conditions. Rev Bras Saúde Mater Infant. 2005:5(1):53-9.

18. Pelegrini A, Silva DAS, Petroski EL, Gaya ACA. Overweight and obesity in seven to nine-year-old Brazilian students: data from the Brazilian Sports Project. Rev Paul Pediatr. 2010;28(3):290-5.

19. IBGE - Instituto Brasileiro de Geografia e Estatística, 2010. Pesquisa de Orçamento Familiares, 2008-2009. Rio de Janeiro: IBGE; 2010.

20. Pesquisa Nacional de Saúde 2013. Rio de Janeiro: IBGE, 2014; 181p. [cited 2018 March 03]. Available from: ftp://ftp.ibge.gov.br/PNS/2013/ pns2013.pdf

21. Fernández $\mid R$, Redden $D T$, Pietrobelli $A$, Allison DB. Waist circumference percentiles in nationally representative samples of African-American European-American, and Mexican-American children and adolescents. Pediatr. 2004;145(4):439-44

22. Li C, Ford ES, Mokdad AH, Cook S. Recent trends in waist circumference and waist-height ratio among US children and adolescents. Pediatrics. 2006;118(5):1390-8.

23. Soar C, Vasconcelos FAG, Assis MAA. A relação cintura quadril e o perímetro da cintura associados ao índice de massa corporal em estudo com escolares. Cad Saúde Pública. 2004;20(6):1609-16.

24. Ricardo GD, Gabriel CG, Corso ACT. Perfil antropométrico e adiposidade abdominal de escolares entre 6 a 10 anos de idade do Sul do Brasil. Rev Bras Cineantropom Desempenho Hum. 2012;14(6):636-46.

25. McCarthy HD, Ashwell M. A study of central fatness using waist-toheight ratios in UK children and adolescents over two decades supports the simple message: "keep your waist circumference to less than half your height'. Int J Obes (London). 2006;30(6):988-92.

26. Pereira PF, Serrano HMS, Carvalho GQ, Lamounier JA, Peluzio MC, Franceschini SC, et al. Waist and waist-to-height ratio: useful to identify the metabolic risk of female adolescents? Rev Paul Pediatria. 2011;29(3):372-7.

27. Brannsether $B$, Roelants $M$, Bjerknes $R$, Júlíusson $P$. Waist circumference and waist-to-height ratio in Norwegian children 4-18 years of age: reference values and cut-off levels. Acta Paediatr. 2011;100(12):1576-82.

28. Lou DH, Yin FZ, Wang R, Ma CM, Liu XL, Lu Q. Neck circumference is an accurate and simple index for evaluating overweight and obesity in Han children. Ann Hum Biol. 2012;39(2):161-5.

29. Coutinho CA, Longui CA, Monte O, Conde W, Kochi C. Measurement of neck circumference and its correlation with body composition in a sample of students in São Paulo, Brazil. Horm Res Paediatr. 2014;82(3):179-86 